\title{
LIMITING THE PROGRAM OF TEMPORARY RESIDENCE PERMITS FOR FOREIGNERS BASED ON REAL PROPERTY INVESTMENT IN LATVIA
}

\author{
Jānis VIESTURS ${ }^{1}$, Iveta PUĶ̄̄TE ${ }^{2}$, Jānis VANAGS ${ }^{3}$, Irakli NIKURADZE ${ }^{4}$ \\ ${ }^{1-3}$ Institute of Civil Engineering and Real Estate Economics, \\ Riga Technical University, Latvia \\ ${ }^{4}$ Dar Building (Ltd.), Georgia \\ Corresponding authore-mail: janis.viesturs@rtu.lv
}

\begin{abstract}
There exists sharp competition amongst nations regarding the increasing foreign investments; therefore, nations are willing to offer foreign investors and their families some type of political bonus, such as temporary residence permit, permanent residence permit, or even citizenship. The simplest way to entice investors is to offer them and their family members temporary residence permits in exchange for investments - simply by purchasing real property (via the so-called "Golden Visa" program). Such a program was launched in Latvia in 2010; however, significant limitations were placed on it in 2014. This research (1) compares the "Golden Visa" programs in different countries in the world, (2) determines the impact of the program on the real property market of Latvia, and (3) searches for the main reason why limitations were applied to the temporary residence permit program in 2014, which resulted in a significant decrease in the international investments in Latvia (this part of the paper is based on the results of the following research: Viesturs, J., Auziňš, A., \& Štaube, T. (2017). Arguments Used for Restricting International Real Property Transactions: Case Study of Latvia).
\end{abstract}

Keywords: Temporary residence permit, foreign real property ownership, international real property transactions, national security.

\section{INTRODUCTION}

Latvia started to offer temporary residence permits in exchange for investments in real property in 2010 and quite suddenly introduced significant limitations to the program in the 4th quarter of 2014. First of all, the aim of the research is to compare similar "Golden Visa" programs in different countries. Secondly, the influence of this program on the real property market in Latvia was assessed, and, finally, the answer to the question why the government significantly limited this program was discovered.

The main arguments used by the governments to limit foreign investments in real property, according to the previous research (Viesturs, J., Auziňš, A., \& Štaube, T. (2017). Arguments Used for Restricting International Real Property Transactions: Case Study of Latvia), are as follows: threat to national security (Vrountas, 1990; Hodgson, Cullinan, \& Campbell, 1999; Gugushvili, 2016), protection of national resources (Lazarus, 1987; Hodgson et al., 1999; Wilson, 2012), threat to national 
sovereignty (Vrountas, 1990; Tirres, 2013; Qin, 2015), anti-immigration policy (Lazarus, 1987; Hodgson et al., 1999; Qin, 2015; Gugushvili, 2016), national and cultural identity protection (Vrountas, 1990; Hodgson et al., 1999; Wood, 2004; Gugushvili, 2016), nationalistic sentiment (Hodgson et al., 1999; Vrountas, 1990; Gugushvili, 2016), xenophobia and sentiment against foreigners (Lazarus, 1987; Wood, 2004; Tirres, 2013), prevention of land speculation (Lazarus, 1987; Vrountas, 1990; Hodgson et al., 1999), prevention of land price increase (Lazarus, 1987; Vrountas, 1990; Fairbairn, 2015), ethnic argument (Lazarus, 1987; Wood, 2004; Tirres, 2013), protection of native farmers (Lazarus, 1987; Tirres, 2013), and questionable allegiance (Lazarus, 1987; Tirres, 2013; Qin, 2015). Thus, the number of applied arguments to limit international real property transactions is extensive.

Despite the program's large contribution to the national economy of Latvia, the high demand for it from investors, real property developers and real property agents, it was significantly limited. Raising the minimum price requirement for a foreigner's real property investment in the "Golden Visa" program from 71139 EUR to 250000 EUR in the 4th quarter of 2014 resulted in a sharp decline of foreign investments in Latvia. The main reason given for limiting this program was due to the threat posed to national security as determined by the Security Police. Attempts to abolish the limits placed on the "Golden Visa" program in the years following have not succeeded because the argumentation of the Security Police has prevailed.

In this research, quantitative data analysis was based on statistical data from the following government agencies: the Central Statistical Bureau of Latvia (n. d.), the Land Registry of Latvia, the Office of Citizenship and Migration Affairs of Latvia (n. d.), and the Security Police (2013, 2014, 2015, 2016). Statistical and comparative analysis of real property transactions was performed as well as the current legislation of Latvia [Immigration Law (2003)] and other countries was analysed and pertinent literature reviewed during the research.

\section{COMPARISON OF TEMPORARY RESIDENCE PERMIT PROGRAMS BASED ON REAL PROPERTY INVESTMENTS IN VARIOUS COUNTRIES}

In today's world, since there exists a great and intense competition amongst nations regarding the increasing foreign investments, nations are willing to offer foreign investors and their families some type of political bonus, such as temporary residence permit, permanent residence permit, or under certain conditions even citizenship. The main goal of the foreign investments is to stimulate certain business ventures that create jobs or aid in the developing of certain economic sectors (e. g., in Australia, Belgium, Canada, France, Germany, Japan, Netherlands, New Zealand, South Korea, United States, etc.). The simplest way to entice investors is to offer them and their family members temporary residence permits simply by purchasing real property.

The Caribbean country - Federation of Saint Kitts and Nevis - stands out from other countries with the fact that beginning in 1984, in order to stimulate the national economy, investors were offered citizenship in exchange for either a 
donation of 250000 USD to the Sugar Industry Diversification Foundation or with a purchase of real property worth at least 400000 USD. Other nations have followed the example of Saint Kitts and Nevis, among them Latvia (Table 1), by offering temporary residence permits if an investment is made in real property.

Table 1. Conditions for temporary residence permits by purchasing real property in selected countries

\begin{tabular}{|c|c|c|c|}
\hline No. & $\begin{array}{l}\text { Country, } \\
\text { program } \\
\text { launched }\end{array}$ & $\begin{array}{l}\text { Value of real property at the time of acquisition } \\
\text { (EUR) }\end{array}$ & $\begin{array}{l}\text { Temporary Residence } \\
\text { Permit (TRP), Permanent } \\
\text { Residence Permit (PRP), } \\
\text { Citizenship (C), Year (Y) }\end{array}$ \\
\hline 1 & $\begin{array}{l}\text { St.Kitts \& Nevis } \\
\quad 1984\end{array}$ & $\begin{array}{l}367410.00 \\
558.00 \text { ( } 300000000.00 \text { USD) donation to Sugar Industry } \\
\text { Diversification Foundation }\end{array}$ & $\mathrm{C}$ \\
\hline 2 & $\begin{array}{l}\text { Latvia } \\
2010\end{array}$ & $\begin{array}{l}\mathbf{2 5 0} \mathbf{0 0 0 . 0 0} \text { (cadastral value not less than } 80000.00)+ \\
\mathbf{5 \%} \text { of the value of real property payment into the State } \\
\text { budget. Since July } 2010 \text { to August } 2014: 71139.00 \text { or } \\
142287.00 \text { (depending on real property location) }\end{array}$ & $\begin{array}{l}\text { TRP } 5 Y \text {, after } 5 \mathrm{Y} \text { can apply } \\
\text { for next } 5 \mathrm{Y}\end{array}$ \\
\hline 3 & $\begin{array}{c}\text { Cyprus } \\
2012\end{array}$ & $\begin{array}{l}\mathbf{3 0 0} 000.00+20000.00 \text { annual income deposited in a } \\
\text { Cyprus bank account }\end{array}$ & $\begin{array}{l}5 Y \text { TRP, after } 5 Y \text { can apply } \\
\text { for PRP }\end{array}$ \\
\hline 4 & $\begin{array}{l}\text { Ireland } \\
2012\end{array}$ & $\begin{array}{l}\text { Mixed investment } 450000.00 \text { real property }+500 \\
\text { of } 000.00 \text { Immigrant investor bond }=\mathbf{9 5 0} \mathbf{0 0 0 . 0 0}\end{array}$ & $\operatorname{TRP} 2 \mathrm{Y}+3 \mathrm{Y}=5 \mathrm{Y}$ \\
\hline 5 & $\begin{array}{l}\text { Portugal } \\
2012\end{array}$ & 500000.00 & $\begin{array}{l}\text { TRP } 2 \mathrm{Y}+2 \mathrm{Y}+2 \mathrm{Y}, \text { after } 5 \mathrm{Y} \\
\mathrm{PRP} 1 \mathrm{Y}+\text { language can apply } \\
\text { for C }\end{array}$ \\
\hline 6 & $\begin{array}{l}\text { Spain } \\
2013\end{array}$ & 500000.00 & $\begin{array}{l}\text { TRP } 1 \mathrm{Y}+2 \mathrm{Y}+2 \mathrm{Y} \text {. After } \\
5 \mathrm{Y} \text { of continuous residence } \\
\text { can apply for PRP. After } 10 \mathrm{Y} \\
\text { of residence can apply for C. }\end{array}$ \\
\hline 7 & $\begin{array}{l}\text { Greece } \\
2013\end{array}$ & 250000.00 & TRP $5 \mathrm{Y}+5 \mathrm{Y} \ldots$ \\
\hline 8 & $\begin{array}{c}\text { Malta } \\
2013 / 2014\end{array}$ & $\begin{array}{l}\mathbf{3 5 0} \mathbf{0 0 0 . 0 0} \text { or by leasing a property for } 5 \text { years or more } \\
\text { with a minimum annual rent of } 16000.00\end{array}$ & TRP \\
\hline
\end{tabular}

Compared to other nations, during the period starting from the 2nd quarter of 2010 until the 3rd quarter of 2014, Latvia had the lowest rate, in the amount of $71139 \mathrm{EUR}$, for real property investment required to obtain a temporary residence permit which granted the holder the opportunity to travel freely in the Schengen zone without a visa. Those who most actively took advantage of this opportunity were the citizens of Russia, the Ukraine, Kazakhstan, China, and many other countries. In 2014, a total of 4982 first-time temporary residence permits were issued to those who qualified by investing in real property. By 2016, based on this criteria, the number of permits issued fell to merely 514. Such a steep decline in the "Golden Visa" program after 2014 significantly affected Latvia's real property market. 


\section{ANALYSIS OF THE REAL PROPERTY MARKET OF LATVIA} DURING THE PERIOD WHEN THE MINIMUM REQUIREMENT FOR THE TEMPORARY RESIDENCE PERMITS WAS INCREASED

After the 3rd quarter of 2014, the total purchase price, the number of international real property purchase transactions (Fig. 1) and the House Price Index (Fig. 2) in Latvia significantly decreased. This did not occur in other Baltic countries (Fig. 3).

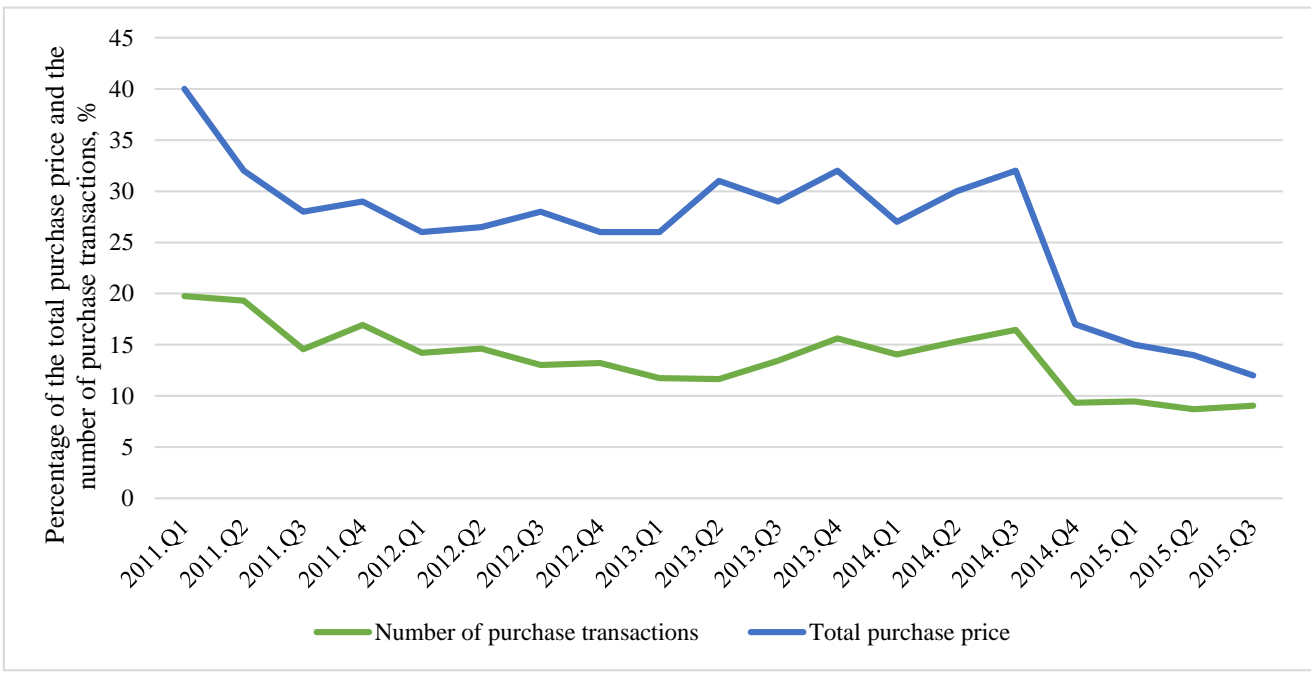

Fig. 1. Dynamics of the percentage of the total purchase price and the number of real property purchase transactions by foreigners in Latvia from 2011 Q1 to 2015 Q3 (developed by the authors based on the data of the State Land Service of Latvia).

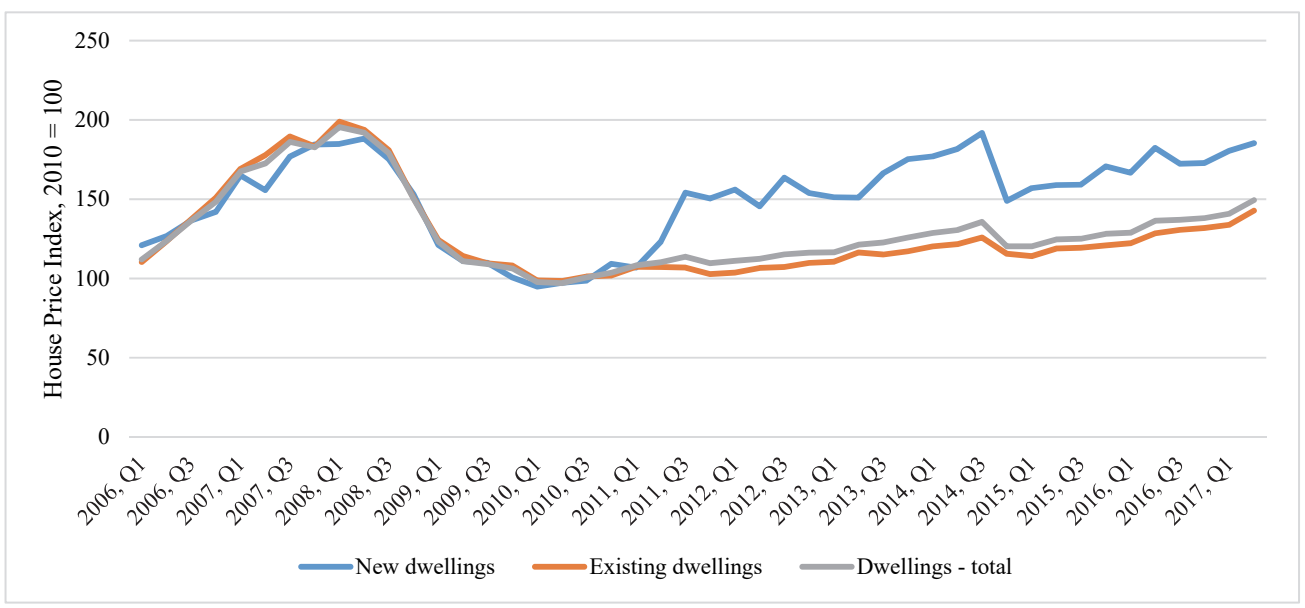

Fig. 2. House Price Index in Latvia from 2006 Q1 to 2017 Q1

[developed by the authors based on the data of the Central Statistical Bureau of Latvia (The Central Statistical Bureau of Latvia, n. d.)]. 


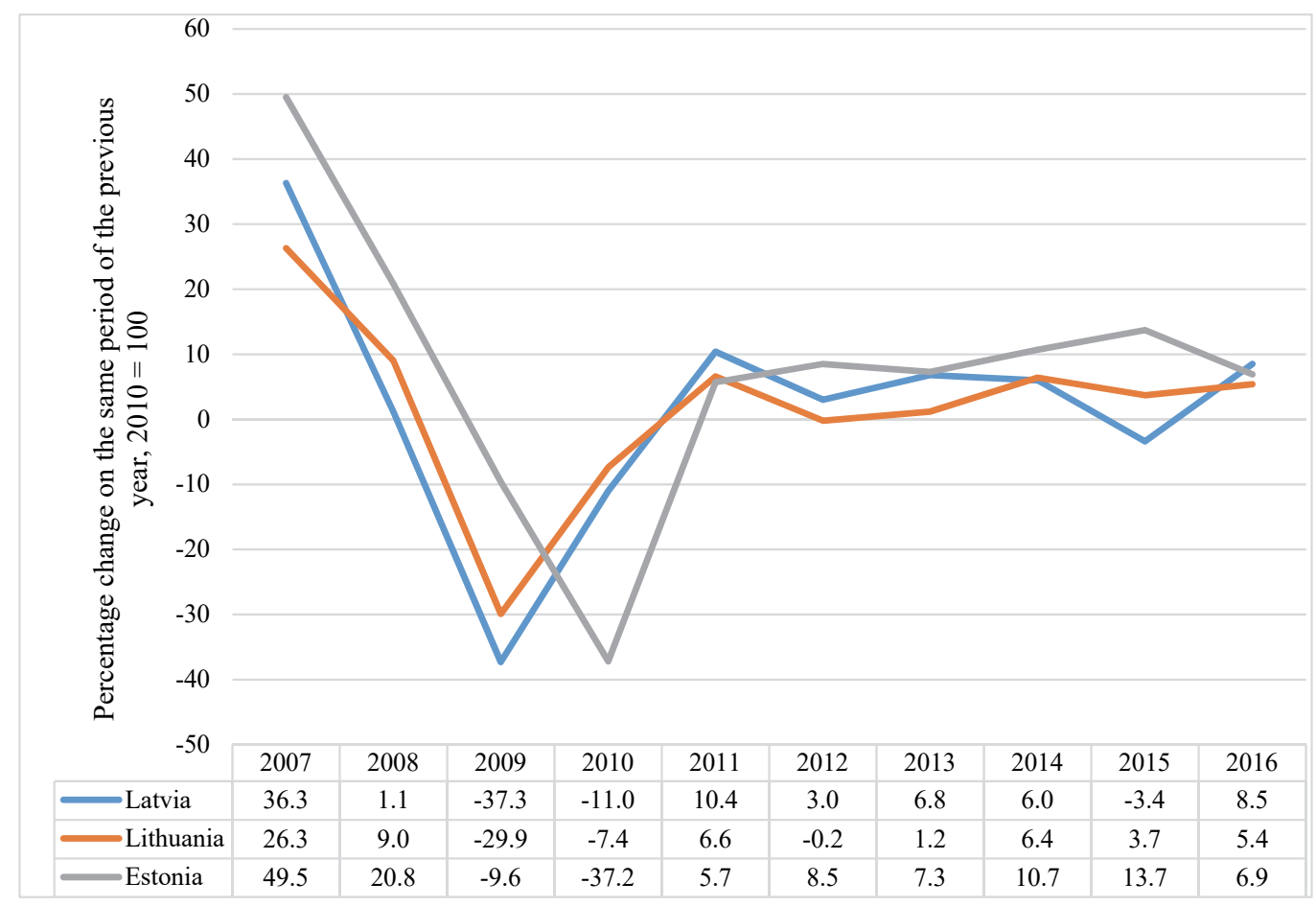

Fig. 3. Residential Property Price Indices in the Baltic States [developed by the authors based on the data from OECD (n. d.)].

The reduction of the number of the international real property transactions was especially observed in the areas where the minimum price to qualify for temporary residence permits was 71139 EUR. These were outside the 'Riga planning region' and outside the nine largest cities of Latvia (Daugavpils, Jēkabpils, Jelgava, Jūrmala, Liepāja, Rēzekne, Rīga, Valmiera, and Ventspils). A drastic decrease was observed, for example, in the cities of Saulkrasti and Cèsis, as well as in the Ozolnieki region, where the share of international transactions in the 4th quarter of 2014 fell from the range of 50-80\% to $10 \%$ (Fig. 4).

The year 2015 was full of difficult challenges for the real property market in Latvia and shifted the market towards domestic demand. Already in 2014, some macroeconomic processes generated a series of events with far-reaching consequences. Changes to the Immigration Law and the fall in the value of the Russian ruble reduced non-residents interest in the Latvian real property market several-fold. Regarding domestic demand, the confusion caused by the application of the "dropped-off keys" principle at the beginning of the year ceased mortgage lending almost completely.

The real property market was able to adapt itself to the new circumstances, and the market avoided a recession which could have occurred (Kauškale \& Geipele, 2016). A specific example was the $18 \%$ increase in the activity in the primary market for new housing during 2015. Despite this fact, there were $12 \%$ less transactions in the Riga (largest city of Latvia) housing market as a whole in 2015, while the total amount of transactions dropped by $22 \%$, with the market losing about 80 million to 100 million euros (Fig. 5). 


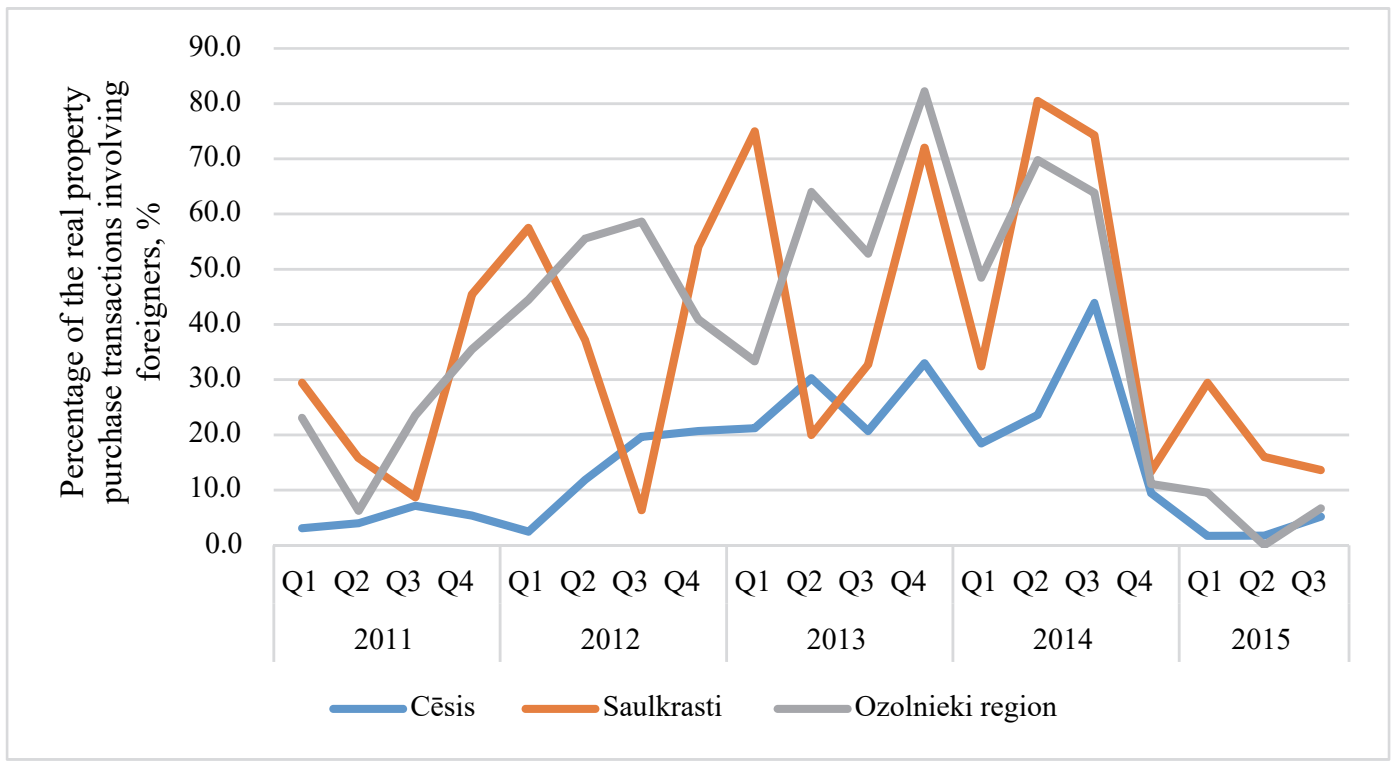

Fig. 4. Dynamics of the percentage of the total number of real property purchase transactions in which foreigners were involved in the cities of Saulkrasti and Cēsis and in Ozolnieki region from 2011 Q1 to 2015 Q3 (developed by the authors based on the data of the State Land Service of Latvia).

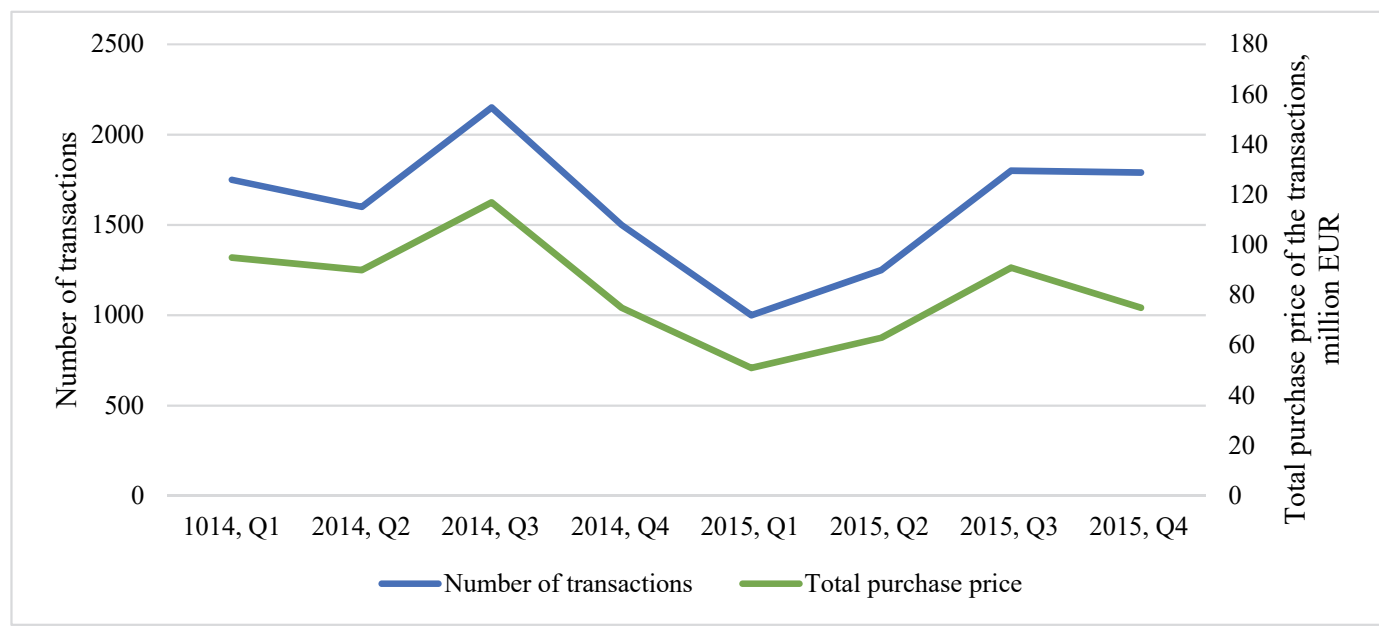

Fig. 5. Dynamics of the total purchase price and the number of transactions with apartments in Riga, 2014-2015 (developed by the authors based on the data from the Land Registry).

The situation in the Riga apartment market was well illustrated by the apartment sector in the city centre: the activity in the Silent Centre, where transactions tend to involve exclusive and non-resident-oriented properties, fell by $56 \%$. The drop in the Remote Centre, which tends to be more focused on domestic demand, was less than $10 \%$ during the year 2015 . 
In the second part of 2015, the market of standard-type apartments returned to its enviably stable volume: about 400 transactions per month for a total amount of 11 million euros. This is the level which was common in 2014.

The 4th quarter of 2015 was marked by continued growth in activity in the primary market of apartments in new developments. During the year, this sector showed an increase in activity by $18 \%$, making 2015 a year of growth. The volume of housing sold by developers demonstrated at least a $20 \%$ increase for three consecutive quarters in the market (Fig. 6).

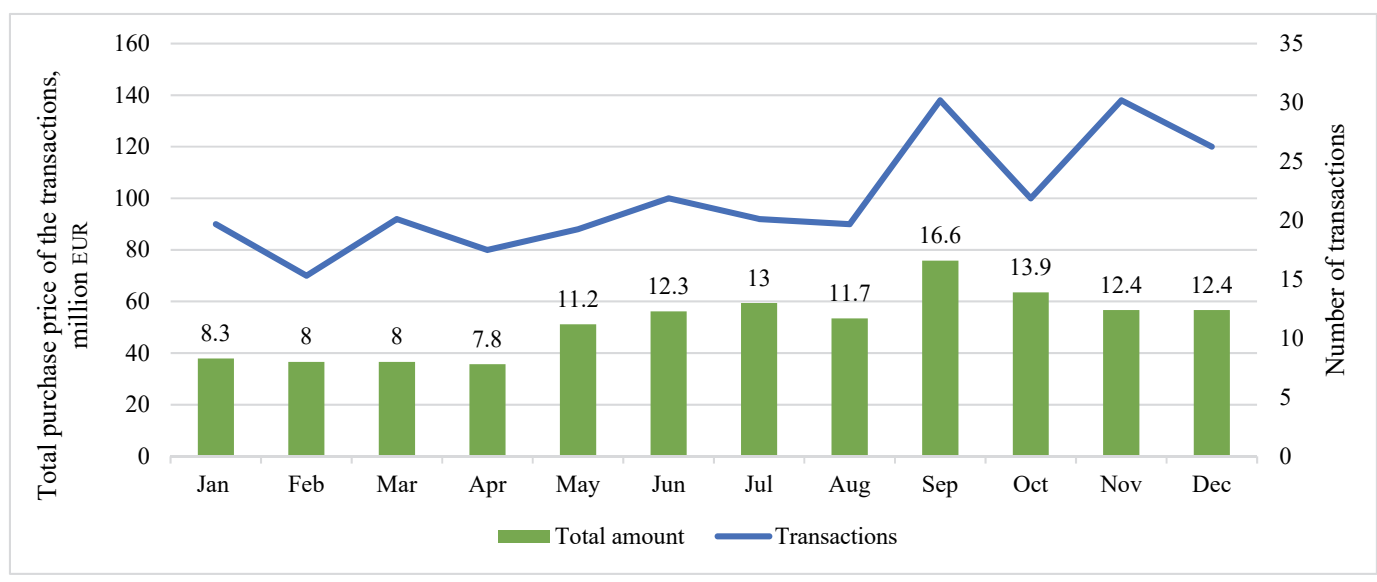

Fig. 6. Dynamics of the total purchase price and the number of transactions with the new apartments in Riga, 2015, million EUR (developed by the authors based on the data from the Land Registry of Latvia).

Despite a good performance in the primary market, the market for apartments in new developments, in terms of both activity and the total amount, decreased in 2015 by about $30 \%$ of all transactions. The secondary market experienced a substantial downturn due to a rapid drop in demand by non-residents. Compared to 2014 , by the end of the year, the number of transactions in this sector decreased by $53 \%$.

The overall market of new developments demonstrated a growth of $13 \%$ in terms of the number of transactions in comparison to the 3rd quarter, yet there was a slight decrease $(6 \%)$ in terms of the amount. In the 4th quarter, the share of the number of transactions with apartments in new developments in the Riga apartment market increased slightly and reached $20 \%$, while the total amount remained at the level of $47 \%$, according to the Land Register data.

The primary market of new developments can more easily adapt to the changing market environment and local demand, with people primarily buying homes for themselves in which to live and custom fine-tuning the layout and finishing materials according to their wishes.

The share of non-residents since mid-2014 in the segment of new developments fell from over $60 \%$ to 20-25\%. It took the market players a year and a half to adapt themselves to the new circumstances, by making price adjustments and sometimes even shifting the business models to rental apartments. 
The 4th quarter of 2015 demonstrated a continued stabilization of prices in new developments, allowing for the assumption that the prices had reached the bottom at the end of 2014 and at the beginning of 2015, and were expected to show a slow, economically justified increase in the future.

The market of new apartments was gradually recovering from the turmoil faced at the end of 2014 and at the beginning of 2015. However, the players were conservative and cautious because the market lacked funding for the down-payment required for a purchase. The dominant decision-making factor was still the price, which was becoming more affordable to buyers in regard to the housing developments oriented towards the domestic demand.

\section{REASONS FOR LIMITING THE TEMPORARY RESIDENCE PERMIT PROGRAM}

There were a number of arguments used in 2014 regarding household growth, real property price increase, tax payments, impact on the labour market and business activities in different sectors of the economy (Silina-Osmane, Ievina, \& Briede, 2014; Blūzma, 2015; Vanags \& Usenieks, 2015) to limit the international real property transactions in Latvia; however, the argument "a threat to national security" prevailed (Viesturs, Auziňš, \& Štaube, 2017).

Before the minimum requirement to obtain temporary residence permits was increased in 2014, the Security Police stated that they lacked capacity to adequately evaluate the large number of requests, i. e., 4982. After 2014, police examination of these requests was more thorough, which was made evident by the number of temporary residence permit rejections or annulments of existing ones. In 2016, the total number of rejections and annulments was 41 , and the three reasons for these are shown in Fig. 7.

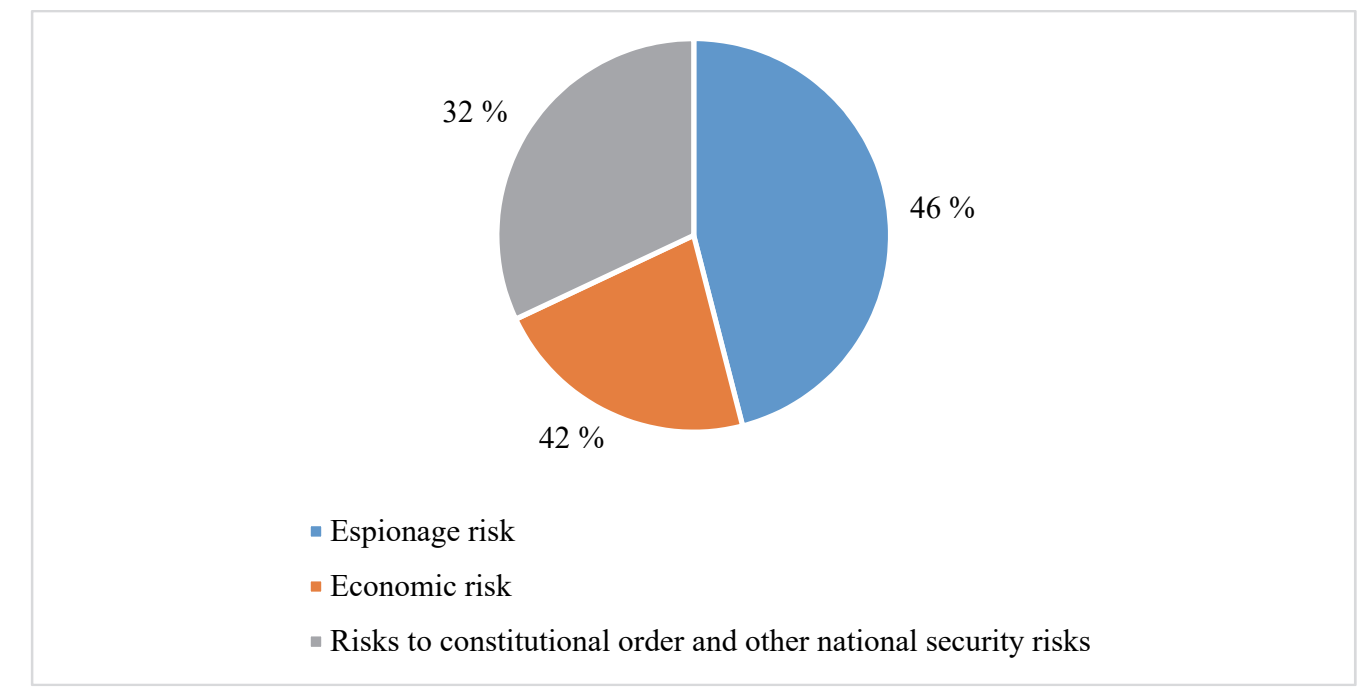

Fig. 7. Reasons given for refusing or annulling temporary residence permits in Latvia in 2016 [developed by the authors based on the data from the Security Police of Latvia (Security Police, 2016)]. 
After changes in the Immigration Law of Latvia in 2014 when the minimal amount of investment was increased to 250000 EUR the Security Police of Latvia in 2015 concluded that the risk to the national security interests of Latvia caused by the program of temporary residence permits had significantly decreased. The Security Police in 2015 and 2016 has continually insisted that lowering of the real property investment requirement necessary to receive residence permits would again pose a risk to national security.

\section{CONCLUSION}

The impact of the "Golden Visa" program on the real property market of Latvia until 2014 was significant. As a result from all investments, the total sum of approximately 1.5 billion euros from direct and indirect investments was added into the economy of Latvia. In some regions of Latvia, the share of real property transactions in which foreigners were involved reached more than $50 \%$. In the segment of new developments, the share of non-residents since September 1, 2014, fell from over $60 \%$ to $20-25 \%$. After short political discussions, the limitations were implemented disregarding the fact that many entrepreneurs had counted on the program and planned business activities in the real property market. The main reason for the limitation of the "Golden Visa" program was the threat to national security. It took the market players a year and a half to adapt themselves to the new circumstances (the market shift towards domestic demand), by making price adjustments and sometimes even shifting the business model to rental apartments.

\section{REFERENCES}

Blūzma, O. (2015, February 10). Re: Latvijas "zelta vīzas" - risinājums īstermin̄ā. Kas pēc tam? Retrieved from Makroekonomika.lv, https://www.makroekonomika.lv/latvijas-zelta-vizasrisinajums-istermina-kas-pec-tam

Fairbairn, M. (2015). Foreignization, Financialization and Land Grab Regulation. Journal of Agrarian Change, 15(4), 581-591. https://doi.org/10.1111/joac.12112

Gugushvili, A. (2016). "Money can't buy me land": Foreign land ownership regime and public opinion in a transition society. Land Use Policy, 55, 142-153. http://doi.org/10.1016/j.landusepol.2016.03.032

Hodgson, S., Cullinan, C., \& Campbell, K. (1999). Land Ownership and Foreigners: A Comparative Analysis of Regulatory Approaches to the Acquisition and Use of Land by Foreigners. FAO Legal Papers Online, 6. Retrieved from http://www.fao.org/3/a-bb039e.pdf

Kauškale, L., \& Geipele, I. (2016). Influence of Economic and Real Estate Market Fluctuations on Real Estate Entrepreneurship in Latvia. In Proceedings of the Sixth International Conference on Industrial Engineering and Operations Management, Malaysia, Kuala Lumpur, March 8-10, 2016. Kuala Lumpur (pp. 851-862). ISBN 9780985549749. ISSN 2169-8767

Legislation of the Republic of Latvia. Immigration Law (2003). Retrieved from https://likumi.lv/doc.php?id=68522

Lazarus, M. L. (1987). An Historical Analysis of Alien Land Law: Washington Territory and State. University of Puget Sound Law Review, 12:197. Retrieved from http://digitalcommons.law.seattleu.edu

Office of Citizenship and Migration Affairs of Latvia. (n. d.). Residence permits in Latvia [Data]. Retrieved from http://www.pmlp.gov.lv/lv/sakums/statistika/uzturesanas-atlaujas.html

OECD. (n. d.). Residential Property Price Indices in the Baltic Countries. Retrieved from OECD. Stat, http://stats.oecd.org/\# 
Security Police. (2013). Annual Report for 2013. Retrieved from Latvian Security Police website: http://www.dp.gov.lv/en/

Security Police. (2014). Annual Report for 2014. Retrieved from Latvian Security Police website: http://www.dp.gov.lv/en/

Security Police. (2015). Annual Report for 2015. Retrieved from Latvian Security Police website: http://www.dp.gov.lv/en/

Security Police. (2016). Annual Report for 2016. Retrieved from Latvian Security Police website: http://www.dp.gov.lv/en/

Qin, X. (2015). A Political Study on Foreign Ownership of Land: Theoretical Challenges and Justifications. Manchester Journal of International Economic Law, 12(2), 195-211. Retrieved from http://www.scopus.com

Siliṇa-Osmane, I., Ievina, I., \& Briede, I. (2014). Trě̌o valstu pilsoṇu uznemšana uzṇēmējdarbības nolūkos Latvijā. Retrieved from European Migration Network, http://www.emn.lv/?p=1724

The Central Statistical Bureau of Latvia. (n. d.). House Price Index in Latvia [Database]. Retrieved from http://data.csb.gov.lv

Tirres, A. B. (2013). Ownership Without Citizenship: The Creation of Noncitizen Property Rights. Michigan Journal of Race \& Law, 19(1), 1-52. Retrieved from http://repository.law.umich.edu/cgi/viewcontent.cgi?article $=1000 \&$ context $=$ mjrl

Vanags, J., \& Usenieks, D. (2015). Terminētās uzturēšanās aț̣auju ietekme uz nekustamo preču tirgu un tautsaimniecību: izvērtēšanas metodikas konceptuāls ietvars. In 56th International Riga Technical University Conference "Scientific Conference on Economics and Entrepreneurship SCEE '2015”. Riga, Latvia, October 14-17, 2015. (pp. 215-216). ISBN 9789934827532

Viesturs, J., Auziņš, A., \& Štaube, T. (2017). Arguments Used for Restricting International Real Property Transactions: Case Study of Latvia. Baltic Journal of Real Estate Economics and Construction Management, 5, 62-75. https://doi.org/10.1515/bjreecm-2017-0006

Vrountas, C. T. (1990). The Necessity and Effectiveness of Barriers to Foreign Direct Investment, B. C. Int'l \& Comp. L. Rev. 167, 13(1), 167-205. Retrieved from http://lawdigitalcommons.bc.edu/iclr/vol13/iss1/7

Wilson, G. (2012). Reforming Alien Agricultural Landownership Restrictions in Corporate Farming Law States: A Constitutional and Policy View From Iowa. Drake Journal of Agricultural Law. 17(3), 709-753. Retrieved from http://eds.b.ebscohost.com

Wood, S. (2004). A Common European Space? National Identity, Foreign Land Ownership and EU Enlargement: The Polish and Czech Cases. Geopolitics, 9(3), 588-607. https://doi.org/10.1080/14650040490478666

\section{AUTHORS' SHORT BIOGRAPHIES}

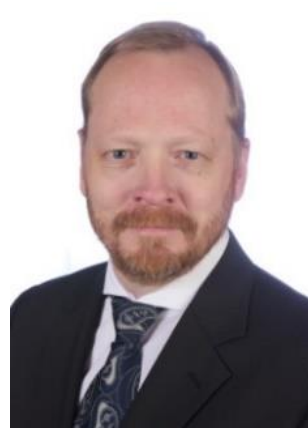

Jānis Viesturs, Mg. oec., is an Assistant Researcher of the Faculty of Engineering Economics and Management at Riga Technical University (RTU). He has more than 20 years of experience in real property management, development, transactions, and due diligence process. He is lecturing the course "International Real Property Transactions". Since 2015, he has participated in scientific conferences, congresses, and workshops. His research interests are real property definition, international and national real property transactions, different real property registration systems, real property due diligence process, and real property management. He is a $\mathrm{PhD}$ student at RTU.

ORCID iD: http://orcid.org/0000-0002-0267-1858 


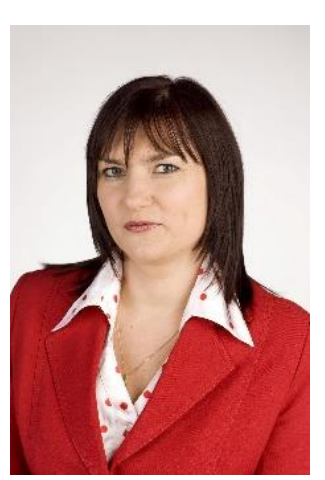

Iveta Pukīte, Mg. sc. ing, a Researcher of the Faculty of Engineering Economics and Management of Riga Technical University (RTU) and a $\mathrm{PhD}$ student at RTU. She received the Academic Master's degree in management sciences from the University of Latvia. She is a Lecturer at the College of Law and the Head of Real Estate Management Department at “Ādažu Namsaimnieks" Ltd. I. Puķīte has participated in the international scientific conference "Economic Science for Rural development", Jelgava, Latvia, in the the 3rd European interdisciplinary forum "Drivers for Progress in the Global Society", Vilnius, Lithuania, and others. Her research area is the socially responsible housing lifecycle of the management system. ORCID iD: http://orcid.org/0000-0003-2500-0501

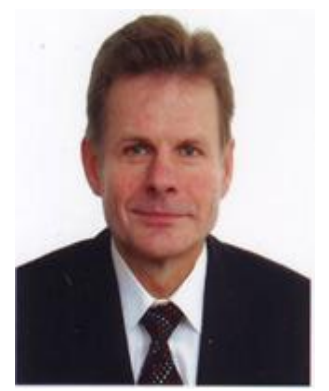

Jānis Vanags is a Professor of the Faculty of Engineering Economics and Management at Riga Technical University (RTU). He received the Doctoral degree in economics from RTU in 2004. His research and teaching interests include national economics, engineering economics, building management, real estate economics, microeconomic and macroeconomic processes, real estate management, and sustainable development. At present, J. Vanags teaches undergraduate and postgraduate courses in national economics, finance market, and real estate economics at RTU.

ORCID iD: http://orcid.org/0000-0002-7570-5457

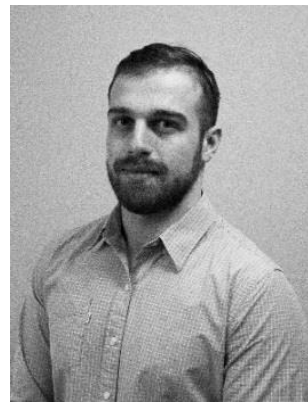

Irakli Nikuradze received the Master's degree in civil construction and real estate management from Riga Technical University, Latvia. He currently provides private real estate appraisal and brokerage services in his hometown Batumi, Georgia. I. Nikuradze participated in the research of Georgian petrol station lease market as an intern at the company "Colliers International Georgia”. His main interests include developing eco-friendly infrastructures, and raising awareness on environmental issues related to excess construction waste dispersal in his hometown. 